Marketing in Asia Group

\title{
"Made in China 2025" Strategy and Trade Hostility: The United States VS China
}

\author{
Md. Salamun Rashidin \\ School of International Trade and Economics \\ University of International Business and Economics (UIBE), Beijing, China

\section{Sara Javed} \\ School of International Trade and Economics \\ University of International Business and Economics (UIBE), Beijing, China
}

\begin{abstract}
The current study provides an overview of the United States and China escalating trade hostility that commenced in January 2018.An attempt has been made to find the root cause of the trade war between two giant economic powers for trade dispute. Mixed method approach was adopted i-e qualitative data was gathered by conducting panel discussion with different professors and quantitative data was gathered from articles, newspapers, WTO, World Bank, WITS and MIT.edu databases. The accumulated qualitative data was analysed through content analysis; excel was used for the quantitative data analysis. Results indicate that evolving tariffs war is a hidden tactic to contaminate "Made in China 2025" industrial revolution Policy, because it's a major hurdle against Trump's wish of making America again super manufacturing power. In fact, China has become a super manufacturing power by upgrading in its technological sector. Moreover, tit for tat tariffs war has reverberated the entire global economy badly. Chinese rapid growth and innovative plan, higher trade deficit between China and the United States, technological development, leading manufacturing capability, foreign investment amiable environment and proper industrial plan "Made in China, 2025" are the main trigger points for the United States. Owing to these reasons, the United States has to impede the Made in China 2025 plan, and it, in fact, wishes to skip Made in China 2030.
\end{abstract}

Keywords: $\quad$ Made in China 2025, Trade War, U.S. VS China, Chinese Trade, US Import 


\section{Introduction}

In 2014, Li Keqiang, Chinese Prime Minister, first introduced the strategy for China's economic development termed as Made in China 2025. It is a comprehensive plan to make the globalized china as advanced manufacturer. It covers entire strategy to develop the information technology, rail, energy, machinery manufacturing sectors, and sustainable economic development. Made in China 2025 will bestow potential access to domestic market, promote research and development capability, and attain the advanced technology from the abroad. In brief, the ultimate goal of this industrial policy is to replace the foreign technology with the Chinese technology gradually. Specifically, the utmost goal of this strategy is to escalate the market share of Chinese suppliers in domestic market up to $70 \%$. Regarding FDI, foreign policy, domestic market conditions, labour cost and living standard are providing comparative advantage to China (Lardy, 2008).

In the broader sense, Made in China 2025 is all round operation of manufacturing deployment strategy which pursues to position the Land of the Dragon on the top of the technological industry. This strategy is expected to bring improvement in ten key areas i.e. innovation, low cost but quality competitive advantages, Green Manufacturing, and Service oriented manufacturing. According to Baldwin (2016), the generations will reap the benefits of the availability of information systems, logistic and low-cost products. China endeavours to make substantial improvement in the robotics sector, energy sector, and aviation among others. It is also diving due consideration to the telecommunication and aerospace equipment manufacturing industries to make them 70-80 \% self-sufficient. In 2001, Chinese policy and structure of export were transformed, presenting it as a high-income country (Schoot, 2006). Rodrik (2006) pointed out that owing to Chinese technological development, a substantial increase has been seen in exports in 2002. Foreseeing the outcomes of Made in china 2025 strategy plan, the United Stated felt threatened. The main tension between the United States and China is that Made in china 2025 is mainly upgrading the Chinese manufacturing industry to ensure sustainable economic development growth (Rashidin et al., 2020a). It's exceedingly evident that if China dominates the tech world, the United Stated could suffer with huge penalties (Preeg.,2004). As a response, Donald Tramp, the United States' President, imposed new tariffs on the Chinese goods claiming that China is stealing the United States' intellectual property. It's clearly understandable that this rage of tariff is not only reducing the deficit, but also grasping the "Made in China 2025" blueprint from triumph execution. The United States is getting a hand on leadership, which has resulted in hampering the trade flow (Hillman, 2018). This move initiated trade war. However, consequent to the announcement of tariffs on Chinese goods by the United States government, china reciprocated by announcing similar tariffs on the United States' goods. According to Winston Mok (2018), "American outrage over 'Made in China 2025' reeks of double standards." According to Kirsty Needham (2018), Peter Navarro, Trumps' advisor, clearly mentioned that the United States actions will target key area of Chinese "Made in China 2025" program; tech market, robotics, and aviation sector among others. 
So, we propose that "Made in China 2025" is the underlying source of triggering the two huge economies towards the trade war. This war doesn't seem to be settling down, and tension is escalating continuously, which may result in a full-blown war that may ripple around the world (Posen, 2018a). So, there is a dire need to investigate. More specifically, there are many studies on Made in China 2025 plan, its outcomes and trade development, but no specific study is found on Made in China 2025 and the United States trade war. This research gap paves the way to these research questions:

i. What are the hidden reasons for trade war between two giant economies?

ii. How and why Made in China 2025 triggers two joint economics towards trade war?

iii. How United States-China ongoing trade tensions agitate the rest of the world?

iv. How and which nations will benefit from the trade war between the United States and China?

The rest part of the paper is structured as follows: methodological design of the study; data collection approach (qualitative and quantitative), introduction of dataset analysis (content analysis, graphs), report findings, and making some discussion. Therewith, conclusion and final discussion entail limitations of this research and potential avenues for future research.

\section{Originality of the Study}

This study is first to explore the hidden reasons behind the United States-China ongoing trade war. In particularly, it will discover how Made in China 2025 policy is triggering the United States to escalate this trade war. Moreover, the study will encompass the impacts of tit-for-tat war and its agitation to rest of the world.

\section{Methodological Design}

\section{Data Collection}

The current study, which is both qualitative and quantitative in nature, adopted mixed method approach (data triangulation). For qualitative data, the researcher gathered first-hand information by conducting panel discussion with different professors. All the professors belong to the field of economics and international trade. Researcher herself/himself recorded the remarks and valuable discussion of professors on the subject being investigated in order to perform an analysis. For quantitative data, the study accumulated secondary data from articles, newspapers, WTO database, World Bank database, WITS database and MIT.edu database. The accumulated qualitative data was analysed through content analysis; excel was used for the quantitative data analysis. We arranged professional interview for higher accuracy of content analysis. However, this semi structured interview is appropriate for limited number of data (Bjornholt \& Farstad, 2012; Rashidin et al., 2019b). The interviewees belong to 
University of International Business and Economics (UIBE), Peking University, Beijing Jiatong University and Beijing University. We sent e-mail to 106 professors and 17 policy makers, but only 30 professors replied and agreed to give interview. Among 30 professors, 21 were Chinese professors, 5 were adjunct professors from United State, and rest 3 were policy makers. Most of the professors were from the field of Political economy, International Trade, and Public Administration. Moreover, around 69 percent of the professors were above 45 years of age. 79 percent of the professors were males, and rest were females. This interview technique is often used with small and informative sample group (Neuman, 2000; Saunders et al., 2003).

\section{Qualitative Data Analysis and Discussion}

The primary data gathered from discussion was analysed by performing content analysis.

\section{Content Analysis}

\section{Q1. Has Made in China 2025 strategy triggered the two giant economies towards trade war? If yes, then why and how?}

Made in China 2025 industrial master plan is a challenge to the advanced economies as well as international companies. Over the upcoming era, this strategy (smart manufacturing) will make China a super manufacturing power by upgrading its manufacturing sector. It facilitates the enterprises in boosting their competitiveness in domestic market and foreign market as well. This strategy intends to target high-tech industries (robotics, railway equipment, aviation, machinery, automotive etc.) that significantly contribute to economic growth in competitive economies.

The leading economies (Germany, Japan, South Korea, Italy, and the Czech Republic), wherein high-tech industries contribute an immense volume in economic development, are vulnerable to industrial policy of China. In over nine European nations, machinery is paramount high-tech industry, and in seven nations, automotive industry got utmost importance. In a nutshell, the prospect of economic development profoundly depends on the production of these high-tech industries. If Made in China 2025 strategy is triumphant, advanced economies won't only face a significant decline in industrial output but see a slacken GDP and upsurge in unemployment rate. Thus, apt reaction will aid the rest of industrial economies to lessen the negative effects of China's industrial plan. Furthermore, Made in China 2025 industrial policy riled the regimes around the globe, and it plays a pivotal role in United States - China trade tensions. In the mid-20th century, the United States was being relished as super manufacturing power. Made in China 2025 policy has smashed this status. Trump aims to regain the status for the United States. The genuine target is China's industrial policy named as "Made in China 2025", because it's a real peril for the West technology leaders (Morrisan, 2019). Chinese government's Ministry of Industry and Information Technology released a Made in China (MIC) 2025 document in 2015 - 
pushing for leadership in robotics, information technology, and clean energy among other sectors. It will boost the Chinese and global economy (Cyrill, 2018). Besides this, Robert Lighthizer, the United States Trade Representative, stated, "These are things if China dominates the world, then it's bad for America". In brief, this innovation agenda will be most vulnerable to United States technological leadership. Consequently, it has triggered the United States for trade war.

\section{War of Tariffs So Far}

The experts believed that imposition of abrupt levies by the United States on Chinese commodities could vitiate the execution of Chinese industrial policy 2025. Trump commenced the first round of battle by imposing the safeguard tariffs on Chinese goods like solar panels, about $\$ 8.5$ billion, and washing machines, about $\$ 1.8$ billion, on Jan 22 with the claim of hurting the United States' solar and washing machines industries. Subsequently, on March 8, the United States imposed further levies on aluminium and steel with this claim that China's bigoted trade practices have made American manufacturers vulnerable and have hence threatened the national security. According to Posen (2018b), this kind of initiative will lead to greater impact on global state own enterprises. China has also been alleged for supplying the cheap quality metal all around the globe. In retaliation, China put heavy duties on American agricultural goods like nuts and wine etc.; around \$3 billion. The war flared up on April 3 when the United States announced the second round of duties, about $\$ 50$ billion, on Chinese electronic commodities like machinery and electronic appliances. China slapped a proposed second wave of tit-for-tat tariffs on 106 American products, especially autos, vessels, aircrafts, and agricultural goods; mainly soybeans etc. Announced list of products which became a victim of second tranche of duties was updated (China excluded crude oil, and the United States removed microtomes, splitting machines, flocking docks etc.) on August 8, which covered about \$ 16 billion imports. Anticipated retaliatory tariffs of second phase would actually take into effect since August 23 from both sides. The trade dispute has not been resolved yet, but it turned into a full-blown war even though China accused the United States for this prolonged trade war in the history. The trade tension is more likely to get worse once third round of the United States - China tariff on plastics and chemicals commodities will be on crosshairs. In third round, both plastic and chemical industries will be at high stake. America plans to hit extra duties of \$200bn on competitor nation imports. Meanwhile, China vows to put retaliatory duties of $\$ 60 \mathrm{bn}$ on American imports. As stated by American Chemistry Council, second wave of tariffs impaired exports of the United States' plastic \& chemical by $\$ 2.0 \mathrm{bn}$ and Chinese exports of these products by $\$ 2.2 \mathrm{bn}$. The forthcoming round will leave further impact on the U.S exports of these commodities, about $\$ 8.8 \mathrm{bn}$, and Chinese exports of these goods, around $\$ 16.3 \mathrm{bn}$. 


\section{Q2. What do you think, in trade dispute, which parties are more likely to win /benefit most or lose with regards to the United States and China?}

The chief loser of this trade war might be the U.S-China consumers. The escalating tensions would also have worse ramifications on producers and all businesses. The economic consequences would be significant particularly for consumer goods up till now. Most of the products in the first list worth \$50bn and second list worth \$200bn have not directly hit the consumer goods. The indirect repercussions would hit the consumers as the United States enterprises are mostly dependent on Chinese machinery, parts and IT etc. and imposed taxes would be inflated, so the cost of business customer (depending on imported parts) would be finally passed on to end users, rattling the financial markets and layoffs so on and so forth. In addition to this, we may be moving to the fourth list like appliances, toys, apparels, footwear, and other commodities, which mainly occupy the shelves of our entire retail outlet manufacture in China. These are the things which are directly obvious to consumers as they buy them on daily basis, so they wouldn't able to avoid getting into caught in the crosshair. As a result, the United States' investor will fall in the same trap due to investing huge amount in China. According to Long (2005), foreign partner investor will no longer be motivated to continue, but Chinese partners can enjoy high profitability in a market protected by the wall of high tariffs.

On the other hand, Trump wants to impose $25 \%$ tariffs instead of $10 \%$, so all the Chinese companies should figure out how long they can sustain $25 \%$ increase. Of course, it is difficult for small companies (particularly in the field of footwear, textiles etc.) to absorb $25 \%$ from head to bottom, as they have low margins in that situation. The consumers will have to pay more at some points. Increased pressure of heavy penalties on producer means that they will have to pay more and translate a price hike for the consumers. In addition to this, the companies have to look for other options, such as finding an alternative supplier or relocation of their factories to Malaysia, or Vietnam; outside of China. If $25 \%$ tariffs will be imposed by the United States, then Intel could also experience a sharp increase in cost of components. As stated by Ives, business icons like Google, Facebook etc. could also augment a minute amount of cost on temporary basis if tit-for-tat war begins. But, it's not only for Chinese and American consumers who are being afflicted, however the trade war between two largest economies is disrupting the global supply chains (like Asia), instigating delays and commodities rollouts. Moreover, farm producers would bear a brunt of tit-for tat tariffs war between the United States and China. This is not a positive practice for development and economic reforms pathway (Drezner, 2014). Farmers of soybeans would experience surge in price by $17 \%$, and they export approximately $60 \%$ of soybeans from China. The escalating tension would spark bitter reverberations, especially on the bottom-line farmers. Mexican producers also felt the ramifications of trade war. Owing to the United States-China trade war, rest of the world is in tension, because it is affecting global financial market, resulting in price fluctuation, and creating more trade imbalance. 


\section{Q3. How will this trade war impact the overall global economy / rest of the world, or where are we going?}

According to IMF's trade data, EU trade is lower than that of the United States, but it is growing faster and has significant trade relation with Asia. So, Asia is important for EU than the United States. According to World Bank and Eurostat data, Chinese private consumer expenditure has been increasing at $13.8 \%$ in the last decade, which is four times faster than that of the United States. Definitely, it's true that China is the largest market for an expensing list of others countries than South Korea, Brazil, Australia, Indonesia, and South Africa. If flow keeps growing in the same way, China will be the largest economy than the United States by 2021 (IMF, 2020). Trump's trade war is creating new push for the EU and Asia to speed up the opening of their markets to forge closer economic connections. EU and Asia are geographically closer than the United States, and Asia and EU are growing faster with high amount of investment. They have fast track Free Trade Agreement (FTA). Within Asia, China and Japan are seeking new trade boundaries and the Regional and Comprehensive Economic Partnership, which is being prioritized as a major step towards Asia's economic integration. In this situation, the direct significance of the Trump trade war is, therefore, faster and wider economic integration outside of the United States and is accelerating the shift of global economic centre of gravity towards Asia. Owing to Asia-EU closer economy, the Trump's tariffs can hamper the export to the EU. It's true that 326 million United States consumers are protected by Trump's tariff. On the other hand, over 4 billion consumers will enjoy better and cheaper product in EU and Asia at $25 \%$ less cost. Chinese manufacturers and United States investors are producing product though pure supply change management. This $25 \%$ extra tariff will hit the global economy. The direct effects will be increased as business confidence drops and investment decisions will be overdue. Markets are still hoping that the key players will return to the negotiation table. If they are not agreed to sit under same roof, then global production price will rise up, and world will adopt the optimal tariffs, consequently total supply chain and $\mathrm{O}$ rings cycles will be hampered. China can turn to Iran, Turkey, and Russia for oil and others comprehensive trade. The global economy will not be blessed by trade war.

In Asia, numerous nations are being afflicted by the ongoing trade war, as many of them export intermediate items to China to be further sold to the United States. According to economists at Capital Economics, prolonged trade tension leaves a considerable impact on other nations too, like Malaysia and Taiwan who export a variety of intermediate goods to China, as decline will be seen in the United States imports from China. Moreover, Marcel Thieliant, a senior Japanese economist at Capital Economists, stated that Japan is directly influenced by tit-for-tat war relatively low as its export for the United States is $19 \%$ and same percentage for China. Volatility of stock market and fluctuations in currency could greatly influence the Japanese economy. Moreover, "Chua Han Teng", head of Asia nation risk at BMI research, articulated that "Asian economies are export oriented nations and are key suppliers of components to China". In addition to this, Hong Kong and Singapore, giant financial hubs, will face the brunt of ongoing trade escalation for relying on 
Chinese manufacturing sector. South Korea could suffer to a great extent from trade dispute as it is a chief trading partner amid the United States and China.

\section{Repercussions of Trade Dispute on Currencies and Equities:}

The trade war could surge the instability in Dollar, though it may have limited impact to the large inclination. The viewpoint of the interest rate will be raised and strong United States economic growth will have a greater say on the movement. Bank of China has RRRS, and it has cut twice within three months. Financial institute like Central Bank endeavours to cope up with the situation by amending the liquidity shortly, nevertheless interest rate will go up. United States-China trade war is hinged with low economic impetus, and impartial Central Bank is bearish to the Yuan [Figure $1]$.

\section{Figure 1: Yuan and USA Flow Graph}

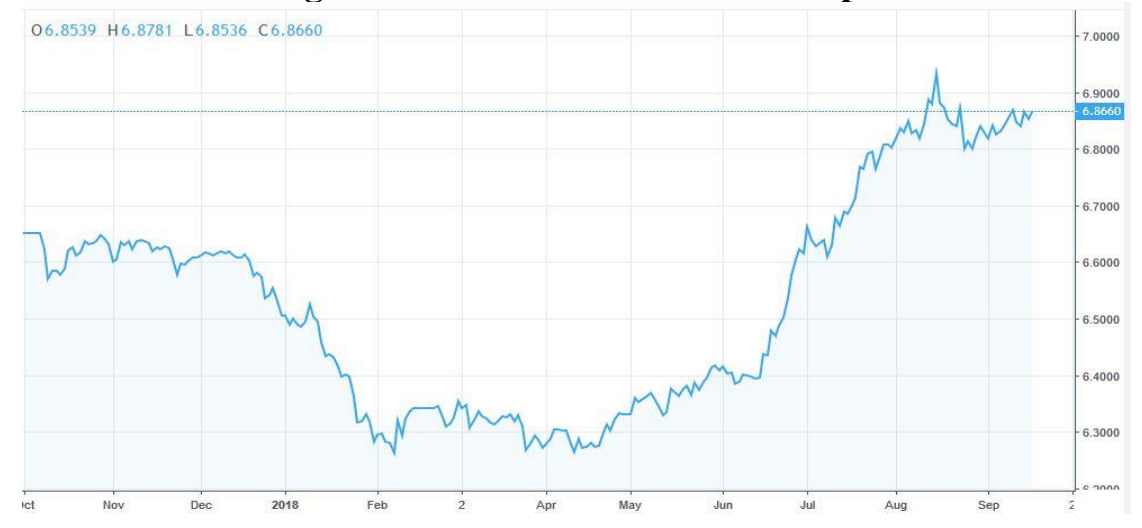

Source: CNBC, 2018

The tit-for-tat tariffs war won't only dip down the stock prices all over the world, but it will leave adverse reverberations on global economy. Imposition of heavy duties will augment the cost of enterprises, surge the uncertainties and lessen the demand. Thus, it is not wrong to say that rising tensions of war will escalate the risk for global business ahead [Figure: 2].

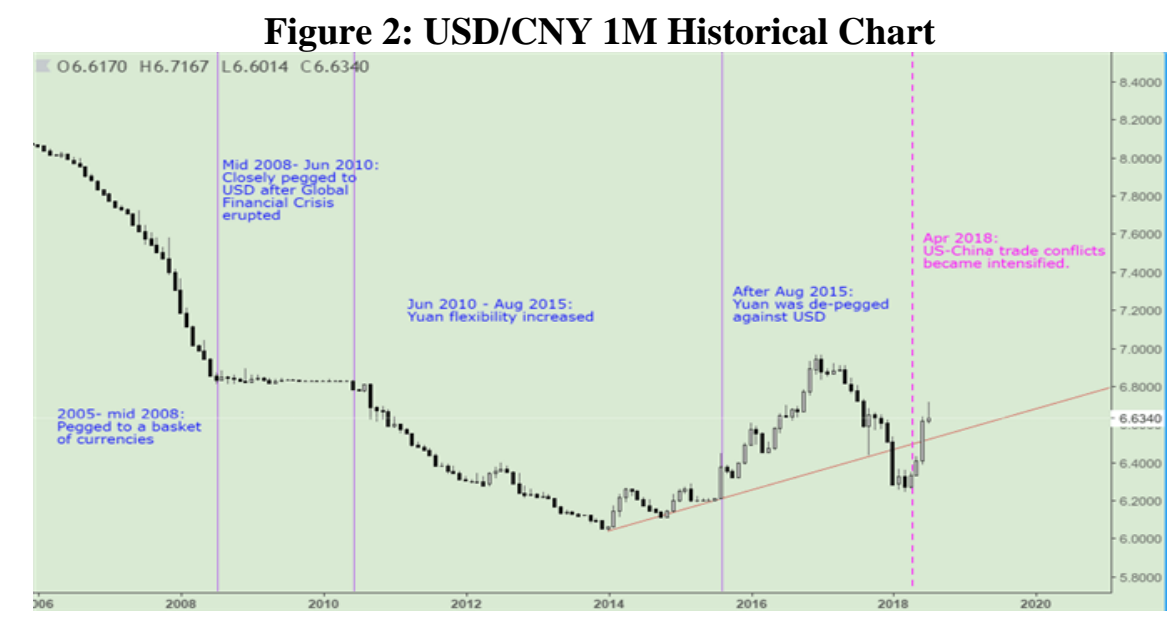

Source: Renee Mu, 2018 
Volatility won't be seen in currencies (Yuan and Dollar) of two biggest economies due to trade dispute, but will be seen in other nation currencies, like Japanese Yen and Swiss franc will benefit from this trade war. Capital may flow from JPY or CHFdenominated assets within lessened risk tolerance and appetite that grasp more cynicism over the constancy of traditional havens like Dollar. Tramp Administration's tariffs on China are also making impact on Australian Dollar. The entire world will suffer due to economic war (Trade War) amid US-China [Figure 3].

\section{Figure 3: Due to Trade War Australian Dollar Fall in Graph}

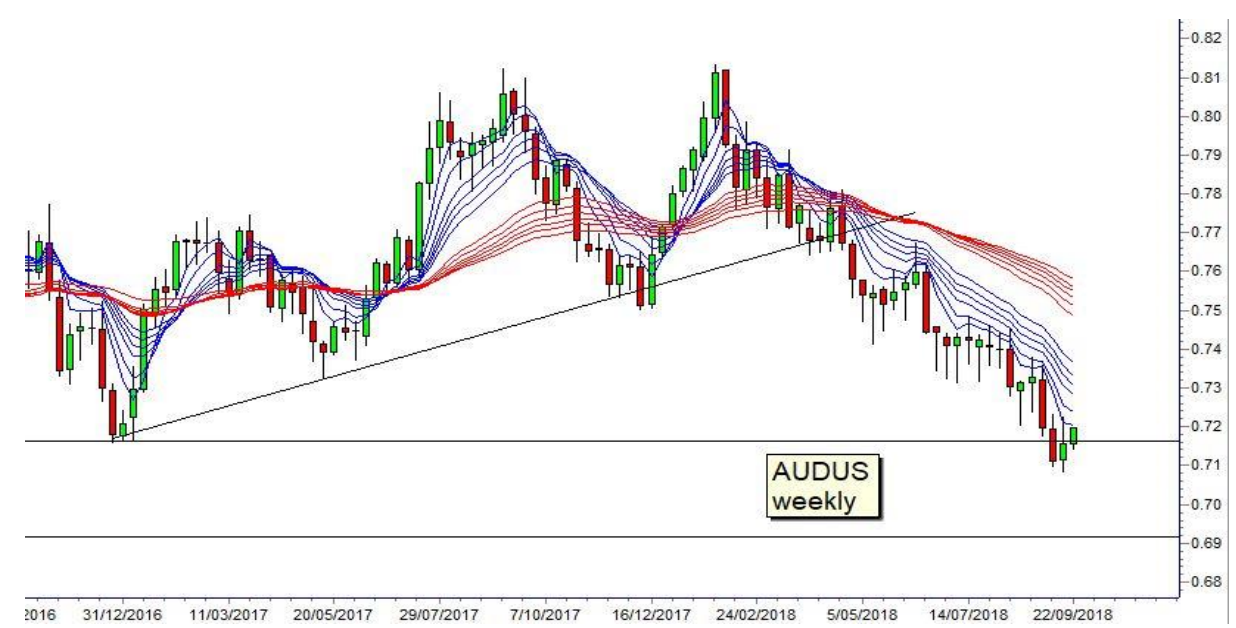

Source: Daryl Guppy, 2018

Graphical representation of Australian Dollar is showing a $\$ 0.74$ fall and has a downside target near $\$ 0.715$. This target is recognized using the support area tested in 2016 and 2017. The merging near $\$ 0.715$ is weak. There is a low probability of a rally rebound towards $\$ 0.74$. Traders fade the gathering for a move towards the next lower level near \$0.69 in 2018 after imposing the Trump tariffs in Australia.

\section{Q4. Which nation is more likely to win trade war; the USA or China?}

Trump Administration has announced new tariffs of 25\%. Trade war started, and it has turned into Cold war. Trump articulated, "Customs mean new employment opportunities, and Customs mean resources". So, point is that if those resources and employment opportunities are the weapon to win trade war, then China will take competitive advantage against the United States. It's not that China will win for one party rules, but it's true that it will give adverse weather for trade war to win. Another reason that China will win the trade war is that it is taking every step very carefully than the United States. Interesting point is that if the United States importers want to import any Chinese production, they need to pay more taxes, and Chinese company needs to pay minimum amount of taxes. After imposing the additional taxes, China has adopted policies to encourage foreign companies to invest in its country. Trump Administration thinks that it will sojourn the Chinese economy and protect intellectual property through the additional taxes. The United States Administration 
believes that Chinese economy depends on exporting products to the United States.

For that reason, china will surrender in front of the United States' claim.

Trade Scenarios of USA and China

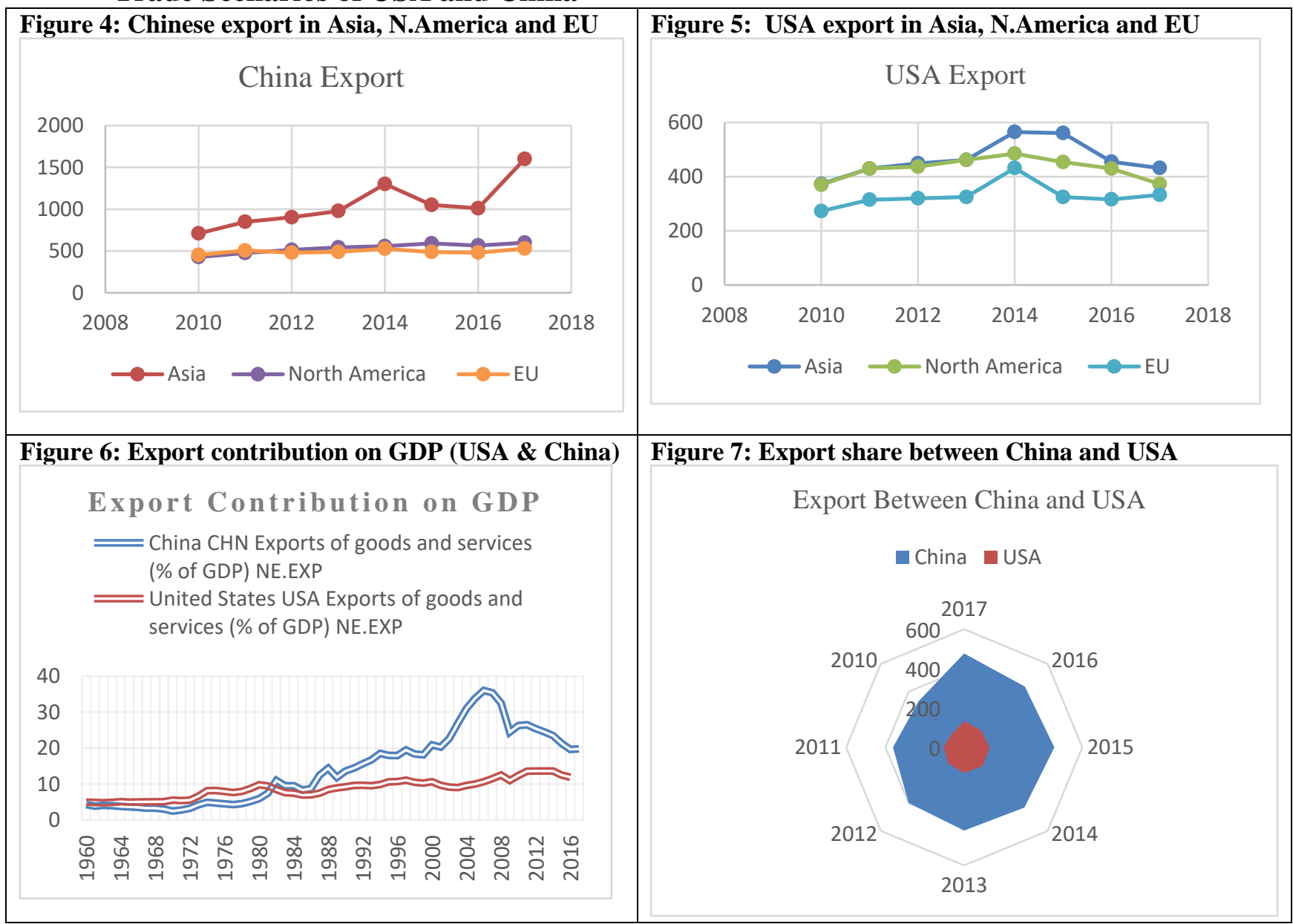

Source: World Bank Mega Data \& MIT, 2018

But real scenario is quite diverse. According to World Bank and MIT.edu (2019) data, China's exports to Asia are worth $\$ 1.07$ trillion dollar, to North America are worth $\$$ 596 billion dollar and to EU are worth $\$ 528$ billion dollar [Figure: 4]. On the other hand, the United States exports to Asia are worth $\$ 432$ billion dollar, to North America are worth $\$ 375$ billion dollar and to EU are worth $\$ 333$ billion dollar [Figure: 5]. Chinese exports are contributing to $19.57 \%$ of total GDP, and USA's exports are contributing to $11.89 \%$ of total GDP [Figure: 6]. Even China's exports to the United States market amounted to $\$ 477$ billion dollar, and the United States exports to Chinese market amounted to $\$ 133$ billion USD [Figure: 7]. It will hamper the United States greatly than China, because China is exporting the products to the United State and China is generating more than 60 percent from the United States owned factories in China. Many of the companies are making customized tools for American manufacturers like computer routers, LED Screens, Navel Motors etc. According to Lovely and Yang (2018), trade war is not only hampering the downstream of producer and global value chain, but also the American economy. 
Game has already begun. In February, the imposition of $20 \%$ taxes on Chinese washing machines has hiked the price by $16.4 \%$ in the United States market. So, increase in taxes is damaging the United States citizens because they are paying more taxes instead of the Chinese producer. Trade war is rising day by day. On the other hand, China has opened comprehensive offer to foreign investors. It means that the United States is going to be isolated from the world. In June 2018, China offered easier conditions to foreign investors to invest in banking, agriculture, and heavy manufacture sector. Car manufacturer company Tesla got offer from China; it can establish industry in china without local ownership. It has stimulated the other companies to invest in China, which will ultimately increase the employment rate. On the other hand, the United States citizens will have to pay more money to buy Chinese products due to excessive customs levy. It will make a negative impression about their government in the mind of the United States citizens. Those who are investing in China right now are being pressurized for extra tariff. For this reason, companies and investors will go to a cautious position on trade with the United States. This will cause loss to the United States in the longer run. Chinese trade policy and Belt Road Project (BRI) will make robust position from Asia to Africa and Europe, which further emboldened the industrial policy "Made in China 2025". It's more open and transparent and provides equal opportunities to domestic and foreign investors [Central government, China]. According to Kimberly Amadeo (2019), "China is the largest foreign holder of U.S. Treasury's. In December 2018, China owned \$1.12 trillion in Treasury's. That's 18 percent of the public debt held by foreign countries. The U.S. debt to China is lower than the record high of $\$ 1.3$ trillion held in November 2013. China buys U.S. debt to support the value of the dollar. Between 2014 and 2016, the dollar's strength increased by 25 percent. The rise forced China to devalue the Yuan. This ensured that its exports would remain competitively priced with those from Asian countries that hadn't tied their currency to the dollar". On the other hand, Chinese another potential advantage is e-commerce, which provides opportunity to SMEs for higher growth (Freund \& Weinhold, 2004; Yadav 2014).

\section{Quantitative Data Analysis and Discussion}

In 2018, Trump, the United States President, declared that the USA wants to reset up the Chinese unfair trade practices. It added the new edge to United States-CHINA trade war. All over the world, both countries are doing trade with each other and others countries. In April 2018, USA, Canada and European Union (EU) imposed tariffs on steel and aluminium items, which are imported from China. On July 6, 2018, the United States government imposed 25\% more tariffs (worth 34 Billion USD) on Chinese items as Trump's new tariff policy. At the same time, China imposed same number of tariffs on the United States products. Four days later, Trump ordered to make list and published $\$ 200$ billion in Chinese products newly imposed tariff (still in process). China quickly responded to the announcement and they stated that this proposed tariff is irrational and unacceptable. Trumps stated that it's necessary for national security and to save the intellectual property of the United States. It will also help reduce the United States trade Deficit with China. 


\section{Overview of China}

China is the biggest export economy and 2nd largest economy in the word. Chinese trade balance is positive and is worth \$1.04T. It is exporting \$2.27T \& importing $\$ 1.23 \mathrm{~T}$. Chinese GDP in 2016 was $\$ 11.2 \mathrm{~T}$, and per capita income was $\$ 15.5 \mathrm{k}$. Chinese major exports and imports commodities are given below in Figure A1, and Figure A2 is demonstrating the export destination and import origin correspondingly.

Figure A1: Chinese Major Export and Import (2018)

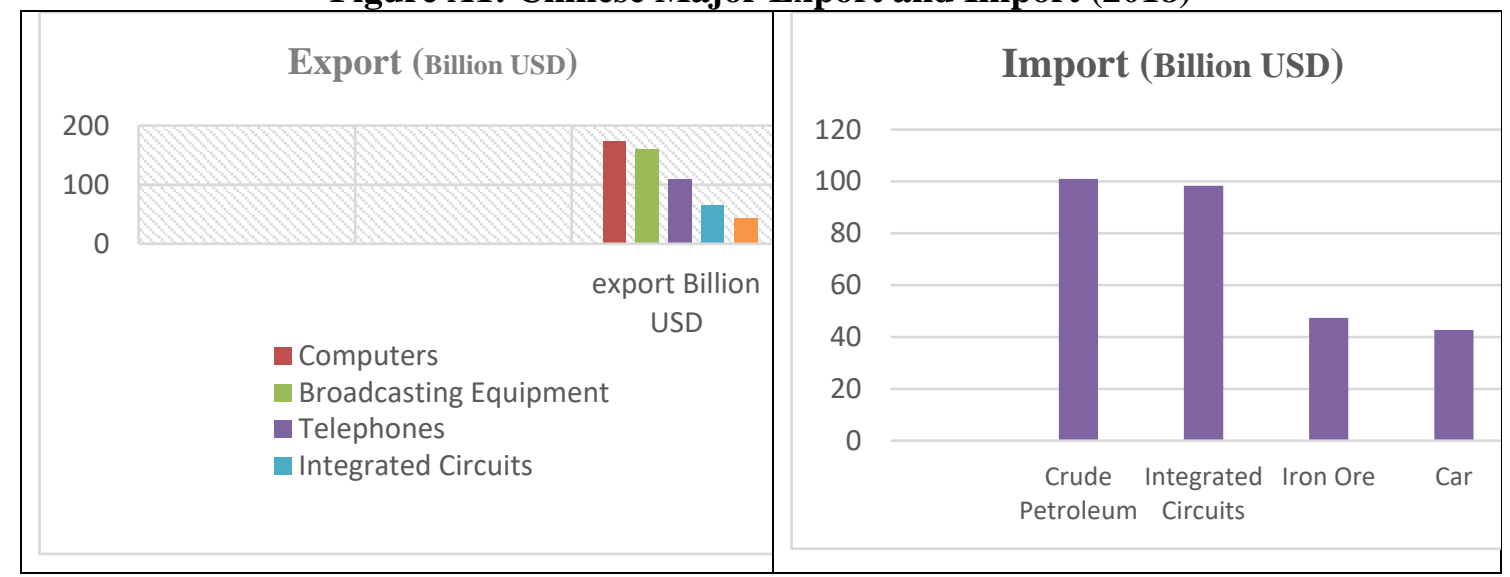

Source: United Nations Statistical Division (COMTRADE), 2018

Figure A2: Chinese Major Export and Import Origin Country (2018)

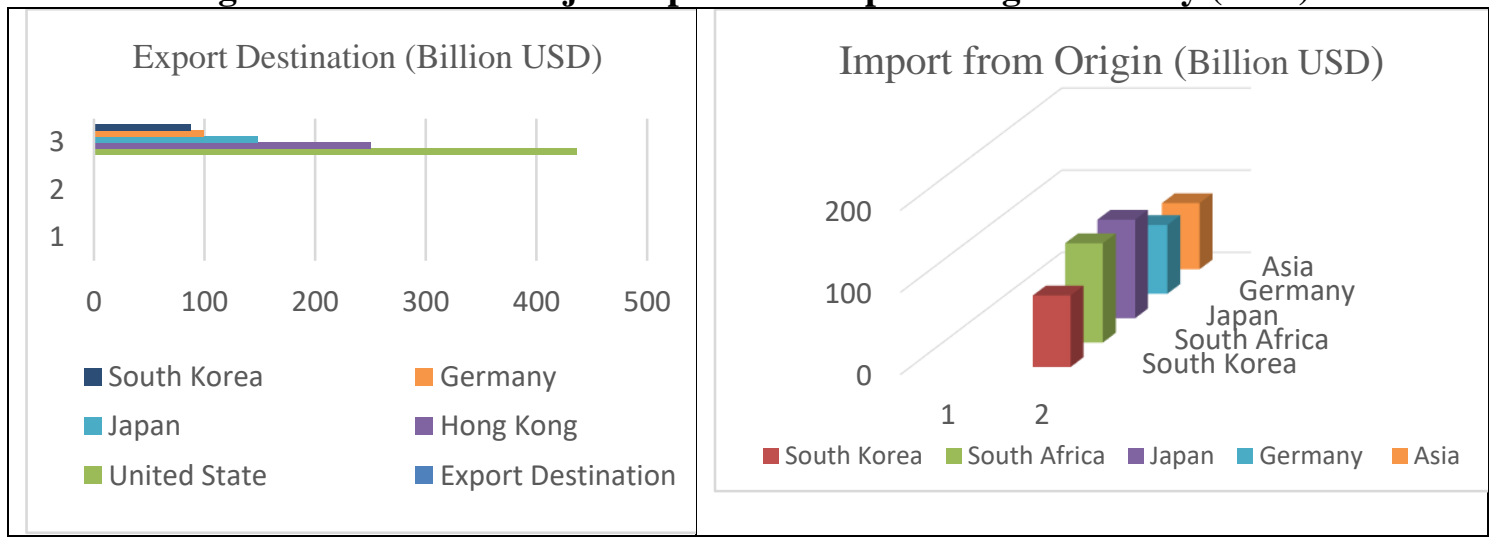

Source: United Nations Statistical Division (COMTRADE), 2018

\section{Overview of USA}

The United States is the $2^{\text {nd }}$ largest export economy and $1^{\text {st }}$ largest economy in the word. United States' trade balance is negative and is worth $\$ 791 \mathrm{~B}$. It is exporting $\$ 1.32 \mathrm{~T} \&$ importing $\$ 2.12 \mathrm{~T}$. USA GDP in 2016 was $\$ 18.6 \mathrm{~T}$, and per capita income was $\$ 57.6 \mathrm{k}$. The United States' major exports and import items are given below in Figure B1, and Figure B2 is depicting the export destination nations and import origin correspondingly. 
Figure B1: USA Major Export and Import (2018)

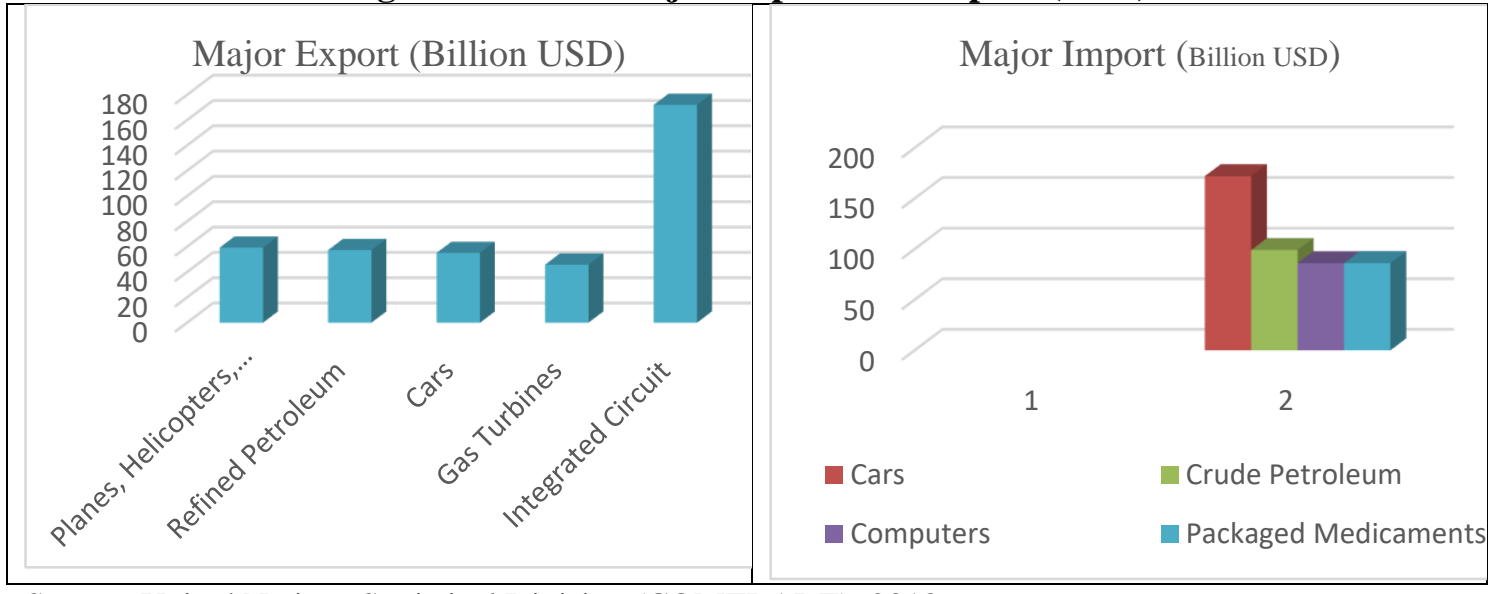

Source: United Nations Statistical Division (COMTRADE), 2018

Figure B2: USA Major Export and Import Origin Country (2018)

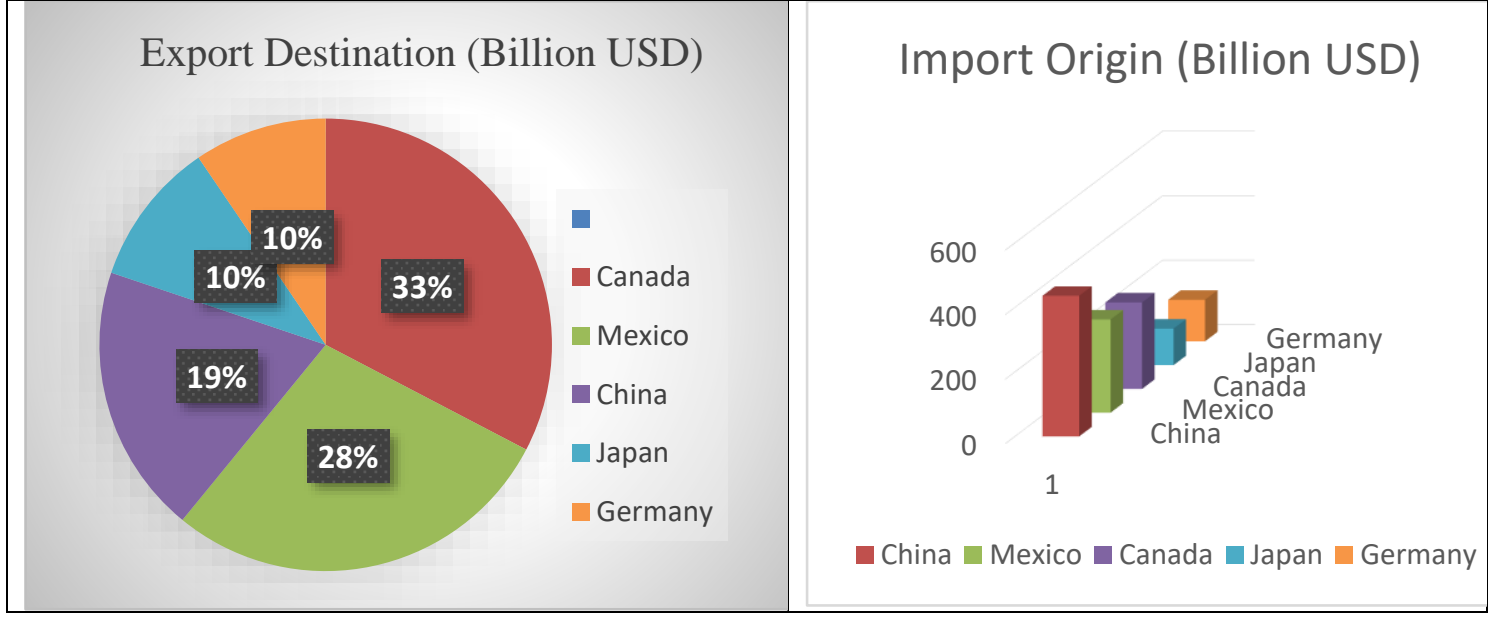

Source: United Nations Statistical Division (COMTRADE), 2018

\section{The US-China Trade War: The Rising Competitor}

Trade deficit with China is no longer issue for the trade war. The possible matter is competition in high technological industry. The United States always complained regarding the intellectual property. In addition to this, "Made in China, 2025" policy is another closest reason for the United States-China Trade war. According to trade data from 1991 to 2016 and from 2016 to 2018, the United States-China Trade relation is changing faster. It is making unavoidable explosion of the trade war. 
Figure 8: US- China Trade War through Export Competition

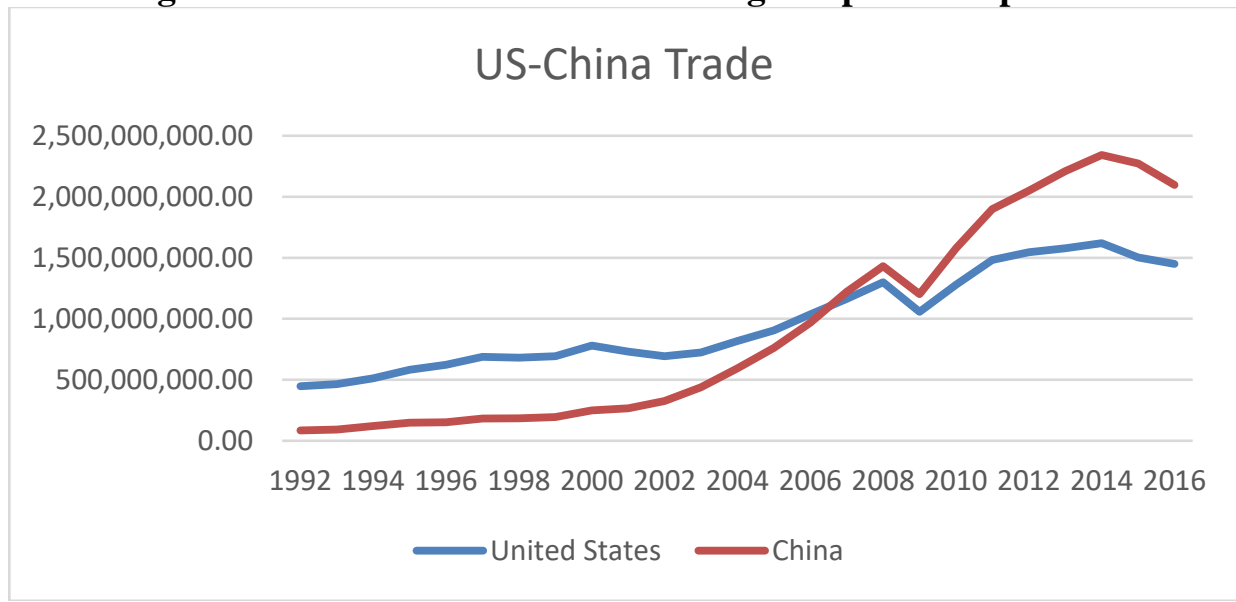

Source: World Bank, 2018

The Figure 8 implies that China's export is rising after 2006-2007. In 2006, China's export was worth $\$ 968935601.01$ US dollar, and the United States export was worth $\$ 1037029245.26$ US dollar, which is higher than China. But, after 2006, the picture has changed. China hit the United States market first time in 2007 by accelerating its export. In 2007, China's export was worth \$ 1220059668.45 US dollar, and USA's export was worth $\$ 1162538149.77$ US dollar, which is higher than last year. Right now, the United States export's total value is \$1450457291.22 US dollar, and China's export's value is $\$ 2097637171.9$ US dollar.

The United States (2015) national strategy towards China was cooperation, and "the scope of cooperation was unprecedented". At that time, National Security Strategy was noted, but in 2017, the game has changed and China has moved to the opponent class. It will no longer relish the growth rates that it has enjoyed for decades. If it wants to continue development, it needs to upgrade the High-tech industry by bringing the innovation. AI or High tech influencing the society in modern era (Hiram et al,2019). So, China already declared that it is growing with quality and swift economic growth by updating the industrial sector like IT sector besides promoting the "Made in China 2025" plan. For the trade war, both of them will pay huge cost.

Table C1: List of Tariffs Imposed Categories by Both China and US in 2018

\begin{tabular}{||c|c|c|c||}
\hline Class & Harmonized System Categories & $\begin{array}{c}\text { China's Tariffs \# of Sub- } \\
\text { Categories } \\
(\boldsymbol{\%})\end{array}$ & $\begin{array}{c}\text { US's Tariffs } \\
\text { \# of Sub- } \\
\text { Categories } \\
(\mathbf{\%})\end{array}$ \\
\hline \hline $\mathbf{0 1 - 0 5}$ & Animal \& Animal Products & 7 & 0 \\
\hline \hline $\mathbf{0 6 - 1 5}$ & Vegetable Products & 81 & 0 \\
\hline \hline $\mathbf{1 6 - 2 4}$ & Foodstuffs & 6 & 0 \\
\hline \hline $\mathbf{2 5 - 2 7}$ & Mineral Products & 0 & 0 \\
\hline \hline $\mathbf{2 8 - 3 8}$ & Chemicals \& Allied Industries & 0 & 8 \\
\hline \hline $\mathbf{3 9 - 4 0}$ & Plastics / Rubbers & 0 & 0 \\
\hline \hline $\mathbf{4 1 - 4 3}$ & Raw Hides, Skins, Leather, \& Furs & 0 & 0 \\
\hline \hline $\mathbf{4 4 - 4 9}$ & Wood \& Wood Products & 0 & 04 \\
\hline
\end{tabular}




\begin{tabular}{|c|c|c|c|}
\hline \hline $\mathbf{5 0 - 6 3}$ & Textiles & 0 & 0 \\
\hline \hline $\mathbf{6 4 - 6 7}$ & Footwear / Headgear & 0 & 0 \\
\hline \hline $\mathbf{6 8 - 7 1}$ & Stone / Glass & 0 & 0 \\
\hline \hline $\mathbf{7 2 - 8 3}$ & Metals & 34 & 181 \\
\hline \hline $\mathbf{8 4 - 8 5}$ & Machinery / Electrical & 0 & 779 \\
\hline \hline $\mathbf{8 6 - 8 9}$ & Transportation & 0 & 92 \\
\hline \hline $\mathbf{9 0 - 9 7}$ & Miscellaneous & 185 \\
\hline
\end{tabular}

Source: World Bank, 2018

The Table C1 shows that tariff target of both the United States and China is \$50B. China always hits the agricultural sector. On the other hand, the United States hits Chinese machinery and IT production sector.

\section{Repercussions of Trade Hostility on Trade and Economy}

Chinese economy is undoubtedly faster, but due to trade war, it has reported a lower GDP and higher dependency ratio as compared to that of the United States. Figure 9 indicates that Chinese GDP was roughly $60 \%$ of American GDP, and China's trade contributed to about $37 \%$ of China's GDP, while the US's trade accounted for only $27 \%$ of American GDP.

Figure 9: US-China Trade VS GDP

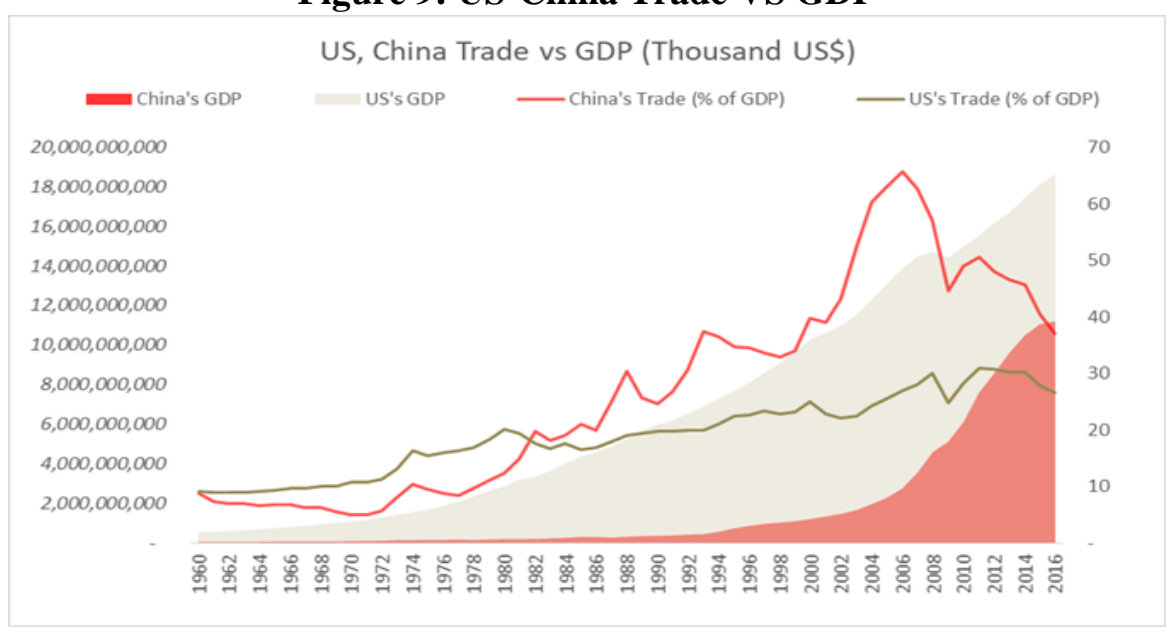

Source: Bloomberg \& World Bank, 2018

Chinese economy was cherishing by having more exports and fewer imports than the United States as shown in Figure.10. 
Figure 10: Imports of China from US

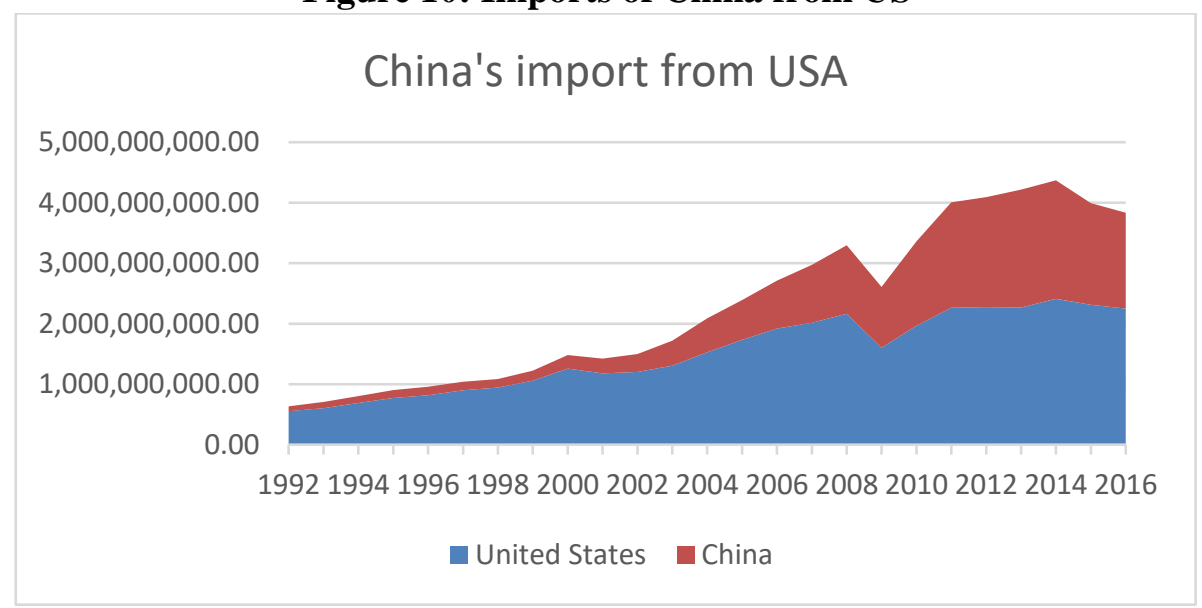

Source: World Bank, 2018

Consequently, the United States experiences trade deficit as demonstrated in Fig.8. But, after the imposition of $25 \%$ heavy tariffs, Chinese economy has experienced the ramifications of tit-for-tat tariffs war. Fig 11 illustrates the bilateral trade of the United States and China from 1991 till 2017. In 2017, statistic shows that the United States import form China was worth $\$ 506$ and export to China was worth \$130 Billion. So, it gives a vivid picture of value of Chinese goods, which are theoretically facing high levies by the United States.

Figure 11: Bilateral Trade US-China (1991-2017)

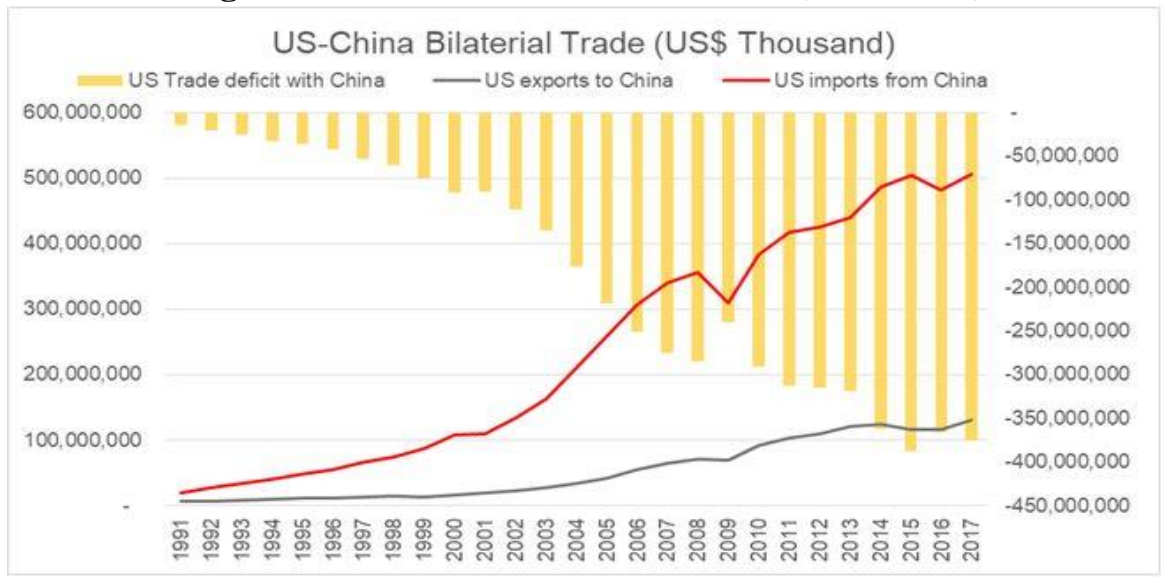

Source: WITS \& Bloomberg, 2018

Moreover, Figure 11 shows that the United States deficit has risen from 1991 till 2017, and it is making a huge gap in bilateral trade. In 2017, the United States imports from china were worth approximately $\$ 500,000,000$ US Dollar, and the United States export was worth only approximately $\$ 1.40,000,000$ US dollar. There is a huge gap of trade balance for the United States. According to Bernanke (2005), the fundamental cause of the United States trade deficit is its saving deficiency. 


\section{Discussion \& Conclusion}

Imposition of heavy tariffs on commodities, which aids in the completion of this strategy, is a hidden tactic to contaminate China Industrial Policy "Made in China 2025 ". But the United States may be successful in slackening the speed of strategy or not to accomplish it by 2025 , however it cannot fully devastate this strategy.

Figure 12: Projection for GDP Growth, 2016-2050

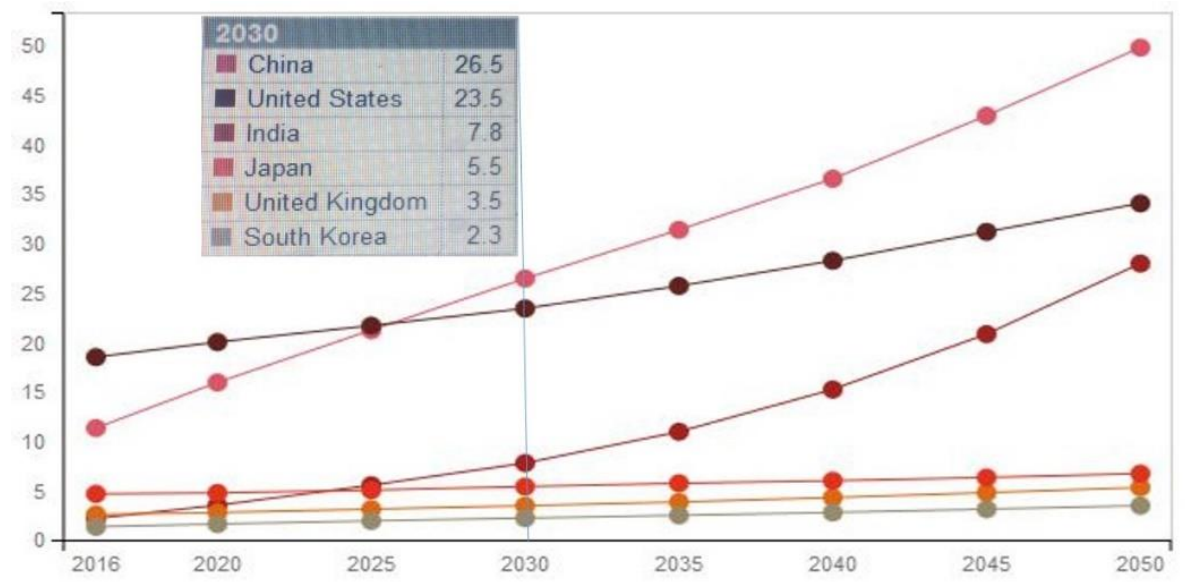

Source: IMF, 2016

China will be the largest economy [Fig:12]. In order to sustain Chinese economy, China is funding in multiple projects; Silk Road or Maritime Silk Road, CPEC, BCIM etc. These connections will help resolve Chinese geopolitics issue as well as improve the supply chain production cycles. According to several researchers (Paul, 1980; Grossman \& Rossi-Hansberg, 2008; Ceglowski \& Golub, 2011; Park \& Hong, 2018; Nyshka Chandran 2018), robust industrial policy aids to cope up increased labour cost as well as influence the economic growth positively. Nevertheless, Made in China 2025 industry policy will play a vital role in boosting up Chinese economy with controlled labour cost.

Besides, The United States government provides huge amount of subsides to make America aim and BUY America act, and it will hamper many foreign competitors such as China. According to Rriedman; Will (2018), "two countries have taken parallels step for comfort" and promoting The Socialist States of America. On the other hand, Chinese government has also updated policy and regulation to attract foreign investor. According to Marvin Dumont (2018), there are several reasons to attract FDI in China, like capital availability, competitiveness, resources availability (physical and labour), regulatory environment, stability, local Chinese market and business climate, and openness to regional and international trade.

Not only these factors are influencing, but governmental policy and regulations on "Made in China 2025" also fascinate FDI such as- 
1. China has issued a document entitled "Several Measures for Enlarging Opening-up and Actively Utilizing Foreign Capital", emphasizing that all regions and departments should ensure consistency in the implementation of policies and regulations.

2. The policies and measures of "Made in China 2025" strategy should be equally applicable to domestic and foreign enterprises, encourage foreign investment in high-end manufacturing, intelligent manufacturing and green manufacturing, and upgrade traditional industries.

3. Supporting foreign capital to participate in infrastructure construction by franchising according to law and regulations and applying relevant supporting policies equally will support foreign investment in establishing R\&D centers and cooperate with domestic enterprises and research institutions in R\&D. This updated law will protect high tech foreign firm technology which argued by most of the nations.

4. Foreign and National cooperation provide equal opportunity as well as protect right for intellectual property rights, support the foreign-funded enterprises to broaden investment and financing channels, and implement the unified registered capital system of domestic and foreign-funded enterprises etc.

5. Local governments are allowed to formulate policies for attracting foreign investment within the scope of their legal powers and protect the rights and interests of foreign-funded enterprises and their investors in accordance with the law. Chinese government considered equal opportunity for domestics and foreign investors. Owing to equal policy, there is minor fiscal control under the Made in China 2025 plan (Oi et al 2012; Xinhuanet.,2020).

6. Government took another initiative for attracting national and foreign investor, such as subsidiaries or preferential policy. According to Zhou et al (2015), preferential policies and package for foreign investors or enterprises include tax incentives, land incentives, foreign tax incentives, regional incentives, investment incentives, development and popularization projects incentive etc. Subsidiary depends on location, particularly in China, and large investors can do negotiation with the local government (Usha \& George, 2013).

Both giant economies are in action line:

According to Office of the United States Trade Representative (2018), the United States took initiative (Action) to protect the Chinese acts, policies, and practice. Trump administrative actions fall in three separated positions; Tariffs, WTO dispute, and Investment restrictions. 
"Tariffs - The President has instructed the Trade Representative to publish a proposed list of products and any tariff increases within 15 days of today's announcement. After a period of notice and comment, the Trade Representative will publish a final list of products and tariff increases.

WTO Dispute - The President has instructed the Trade Representative to pursue dispute settlement in the World Trade Organization (WTO) to address China's discriminatory technology licensing practices.

Investment Restrictions - The President has directed the Secretary of the Treasury to address concerns about investment in the United States directed or facilitated by China in industries or technologies deemed important to the United States".

Report of the USTR clearly concludes that The Chinese government's technology transfer and intellectual property policies are part of China's stated intention of seizing economic leadership in advanced technology as set forth in its industrial plans, such as "Made in China 2025." To safeguard against the Chinese harmful initiative, President Trump has made it clear, "we must insist on fair and reciprocal trade". In the same report stated from EU Chambers of commerce entitle "The European Union Chamber of Commerce in China likewise concluded in a report entitled "China Manufacturing 2025: Putting Industrial Policy Ahead of Market Forces" that there has been an "unprecedented wave of outbound investments" in recent years from China into firms in industries of relevance to Made in China 2025, and many of these investments have been in areas where foreign business is unable to make equivalent investments in China. But, as a quick response from the sides of China, Beijing announced own duly on American products, agricultural products and automobiles, covering 25\% of customs and tariffs (Mofcom, 2018; Cheng \& Evelyn, 2018).

In conclusion, the United States tariff and others action plan are target point of "Made in China 2025" program, which Trumps advisor Peter Navarro clearly told in the press releases. In order to further slowdown this Chinese program, they added technology, robotics, and aviation sectors (Kirsty Needham., 2018). So, we argue that this is the hidden tactic to contaminate "Made in China 2025".

\section{Limitations and Future Directions}

The current research underlies limitation. The main concern is to recognize the underlying motive behind this trade war. We argue that "Made in China 2025" is the only triggering source of confrontation between two giant economies. Nowadays, WTO is also pondering to omit the United States for the survival of global economy. On the other hand, it's true that all nations are engaged to do trade with the United States, but due to trade dispute and internal geo politics, they are experiencing a problem. If this monopoly continues, then it will be hard to sustain the United States policy. The future research could explore more deeply the hidden reasons of this trade 
war, which is rippling around the globe, resulting in increase in the validity of our research.

\section{Practical Implications for Asian Business}

Researchers, academicians and policy makers of least developing Asian nations can get benefit from this study as it uncovers the critical area of the United States-China trade fact, and political strategy. The conflict between the United States and the People's Republic of China presents a stumbling block to the global manufacturing and international trade that has driven growth and prosperity in Asia. In points of view, Asian policy makers are now looking for ways to cushion their economies from the effects of the trade conflict and to help ensure that trade remains an important driver of growth.

Through this study, policy makers can implement the policy for sustainable Chinese economy development. Both the countries are face to face for the action plan. The open agenda varies on the imposition of new tariffs listed products by taking support of divergent claims. The situation is that world is going to exclude the United States concern due to regional geopolitics, and higher proportion of giving VATO (trade restrictions) from the United State to other countries like Russia, China, Iran, Japan etc. Due to higher tariffs, strategic actions and policy modifications, the global economy and other states are worried about the future unfortunate situation. Recently, China funded in a mega project named as Belt and Road Initiative (BRI). It vividly demonstrates that most of the low developing countries signed the project and China invested trillion of Dollars in this project. To do branding of Made in China 2025 project, Asian Country like Bangladesh, Pakistan, Malaysia, Myanmar etc. will get benefit because CPEC, BICM project is connect with BRI and it enhance the MIC 2025. On the other hand, the United States and EU (developed) countries are not considering it positively due to faster Chinese development. They are trying to delay Chinese development. If this scenario become permanent the global chain will hamper consumers, adjust new markets prices and stronger trade ties within Asia and between Asia and other regions, such as the EU, compensate for the disruption. This paper estimates the effects of tariffs on gross domestic product, exports, and employment across countries tech sector. Additionally, this study shows, trade conflict is not just bilateral but global, with many countries hit by the first wave of tariffs on steel, aluminium, washing machines, and solar panels and retaliating against them, even as a new wave of tariffs is threatened against auto and auto parts. It is therefore important to understand and quantify the risks to Asian economies posed by the measures already implemented, as well as those that may follow. Underlying Asia's growth strategy was an assumption that free trade provided the opportunity to benefit from ever longer global value chains, where each production unit is built to minimize costs, maximize efficiency, and foster innovation through international partnerships. Therefore, Asian countries especially developing country like Bangladesh, Pakistan, Bhutan, Nepal etc can take proper initiative to develop policy and protect economy. Because most of the countries are depending on Chinese production supply chain 
management. In this scenario, our study helps sort out how china and other nations should take steps and make policy to continue development with the same pace.

\section{References}

Almond, R. G., (2018), "The US-China trade war: A simple plan: Action, confusion, and retreat", Retrieved from https://thediplomat.com/2018/05/the-u-s-china-trade-war/

Amadeo, K., (2018), "US trade deficit with China and why it's so high", Retrieved fromhttps://www.thebalance.com/u-s-china-trade-deficit-causes-effects-and-solutions3306277

Baldwin, R., (2016), The great convergence: Information technology and the new globalization, The Belknap Press of Harvard University Press, Cambridge.

Bernanke, B. S., 2005, "The global saving glut and the U.S. current account deficit," a paper presented at the Sandridge Lecture, Virginia Association of Economists, Richmond, Virginia, 14 April.

Bjørnholt, M., \& Farstad, G. R., (2012), "Am I rambling? On the advantages of interviewing couples together", Qualitative Research, vol. 14, no. 1, pp. 3-19.

Branstetter, L., \& Lardy, N., (2008), China's embrace of globalization, Cambridge University Press, New York.

Ceglowski, J., \& Golub, S., (2011), "Does China still have a labour cost advantage?", Global Economy Journal, vol. 12, no. 3, pp. 2756-2763.

Cheng, H., \& Park, A., (2018), "Can Chinese manufacturing firms cope with rising labour costs?", HKUST IEMS Thought Leadership Brief Series 2018-21, HKUST Institute for Emerging Market Studies.

Cheng, E., (2018), "China announces retaliatory tariffs on 34 billion worth of us goods including agriculture product", Retrieved from https://www.cnbc.com/2018/06/15/ch ina-announces-retaliatory-tariffs-on-34-billion-worth-of-us-goods-including-agricultur e-products.html

Cyrill, M., (2018), "What is made in China 2025 and why has it made the world so nervous?", Retrieved from https://www.china-briefing.com/news/made-in-china-2025/

David, (2017), "China-US trade war the single biggest economic threat to Australia", Retrieved from: http://www.abc.net.au/news/2017-01-11/trade-war-between-us-and-chi na-a-major-threat-to-australia/8172562

Donnan, S., Jacobs, J., Niquette, M., Han, M., Black, J., \& Deaux, J., (2018), "Economics: U.S., China impose new tariffs on each other as talks resume", Retrieved from: https://www.bloomberg.com/news/articles/2018-08-22/u-s-china-restart-trade-talks-asbillions-more-in-tariffs-loom

Drezner, D. W., (2014), The system worked: How the world stopped another great depression, Oxford University Press, Oxford.

Freund, C., L., \& Weinhold, D., (2004), "The effect of the Internet on international trade", Social Science Electronic Publishing, vol. 62, no. 1, pp. 171-189.

Friedman, T., (2018), “Are we becoming too like China?" The New York Times, 9 May 2018, p. A25.

Giles, C., (2018), "IMF chief warns trade war could rip apart global economy", Retrieved from: https://www.ft.com/content/c8c4bb22-3ccd-11e8-b9f9-de94fa33a81

Grossman, G. M., \& Rossi-Hansberg, E., (2008), "External economies and international trade redux", Retrieved from https://www.nber.org/system/files/working_papers/w12721 /w12721.pdf

Hiram, T., Fam, K. S., Chan, Y. W., \& Cheah, J. H., (2019), "Editorial - Ten trends shaping the future of marketing: Consideration for the academics", Asian Journal of Business Research, vol. 9, no. 1, pp. I-IX. 
Hillman, J., (2018), “The best way to address China's unfair policies and practices is through a big, bold multilateral case at the WTO," Retrieved from https://www.law.georgetow n.edu/news/professor-from-practice-jennifer-hillman-testifies-on-addressing-chinesemarket-distortions/

Krugman, P., (1980), "Scale economies, product differentiation, and the pattern of trade," American Economic Review, vol. 70, no. 5, pp. 950-959.

Lardy, N., (2018), "Prospects for economic reform and medium-term growth in China," Retrieved from http://www.iberchina.org/files/2018-2/Prospects_economic_reform_ch ina_Lardy.pdf

Long, G. Q., (2005), “China's policies on FDI: Review and evaluation,” Retrieved from https://www.cgdev.org/sites/default/files/9780881323818-Ch12.pdf

Lovely, M., \& Yang, L., (2018), "Trump tariffs primarily hit multinational supply chains, harm US technology competitiveness," PIIE Policy Brief, 18-12, May, Washington DC.

Lu, F., \& Li, S. S., (2018), "Reorientation of the U.S. economic and trade policies towards China and the growing risks of trade war between the two countries," International Economic Review, vol. 10, no. 3, pp. 64-86.

Ministry of Commerce of the People's Republic of China (MOFCOM), (2018), “对美加征关 税商品清单序号” Retrieved from: http://images.mofcom.gov.cn/www/201806/20 180616015345014.pdf]

Neuman, W. L., (2000), Social research methods: Qualitative and quantitative approaches, Allyn and Bacon, Boston.

Nyshka, C., (2018), "Responds to Trump tariffs with proposed list of 128 US products to target", Retrieved from https://www.cnbc.com/2018/03/22/china-responds-to-trumptariffs-with-proposed-list-of-us-products-to-target.html

Obstfeld, M., (2018), "Global economy: good news for now but trade tensions a threat", Retrieved from: https://blogs.imf.org/2018/04/17/global-economy-goodnews-for-nowbut-trade-tensions-a-threat/

Oi, J., Babiarz, K., Zhang, L., Luo, R., \& Rozelle, S., (2012), "Shifting fiscal control to limit cadre power in China's townships and villages", The China Quarterly, vol. 211, pp. 649-675.

Posen, A. S., (2018a), "The post-American world economy: Globalization in the Trump era", Foreign Affairs, March/April.

Posen, A. S., (2018b), "The post-American world economy: Globalization in the Trump era", Foreign Affairs, March/April.

Preeg, E., (2004), The threatened US competitive lead in Advanced Technology Products (ATP), Manufacturers Alliance, Washington.

Rashidin, M. S., Javed, S., Chen, L., \& Jian, W., (2020a), "Assessing the competitiveness of Chinese multinational enterprises development: Evidence from electronics sector", Sage Open, vol. January-March 2020, pp. 1-20.

Rashidin, M. S., Javed, S., \& Liu, B., "What a dilemma? Chinese economics growth strategies using IR theories", Chinese Political Science Review, vol. 5, pp. 148-176.

Rashidin, M. S., Javed, S., Liu, B., Wang J., \& Rajest, S. S., (2019), "Insights: Rivals collaboration on belt and road initiatives and Indian recourses", Journal of Advance Research in Dynamical \& Control Systems, vol. 11, no. 4, pp. 1510-1522.

Rodrik, D., (2006), “What's so special about China's exports?”, NBER Working Paper No. 11947, National Bureau of Economic Research, Cambridge.

Saunders, M., Lewis, P., \& Thornhill, A., (2003), Research methods for business studies. Pearson, Washington.

Schott, P. K., (2006), "The relative sophistication of Chinese exports", NBER Working Paper No. 12173, National Bureau of Economic Research, Cambridge.

Usha C. V. H., \& George, T. H., (2013), Subsidies to Chinese industry: State capitalism, business strategy and trade policy, Oxford University Press, Oxford. 
USTR (United States Trade Representative), (2018), "Report to Congress on China's WTO compliance", Retrieved from https://www.innovation4.cn/library/r23475

Wayne M. M., (2019), "The Made in china 2025 initiative: Economics implications for the United States", Retrieved from: https://www.google.com/url?sa=t\&source=web\&r ct=j\&url=https://fas.org/sgp/crs/row/IF10964.pdf\&ved=2ahUKEwjxqqCS3MzkAhWM J1AKHRYnCCk4ChAWMAN6BAgHEAE\&usg=AOvVaw2nrYGvos0Ysak-t3eBd5x $\mathrm{W}$

White House, (2018), "President Donald J. Trump is confronting China's unfair trade policies", Retrieved from: https://www.whitehouse.gov/briefings-statements/presidentdonald-j-trump-confronting-chinas-unfair-trade-policies/

White House, (2018), "Statement on steps to protect domestic technology and intellectual property from China's discriminatory and burdensome trade practices", Retrieved from: https://www.whitehouse.gov/briefings-statements/statement-steps-protectdomes tic-technology-intellectual-property-chinas-discriminatory-burdensome-tradepractices/

Will, G., (2018), The socialist states of America, Washington Post, 8 July, p. A17.

Wiseman, B., (2018), "US-China trade war elevates the risks to the global economy" Retrieved from: https://apnews.com/f8afd2ff1c41409783095052f1dcfb6b

Xinhuanet, (2020), "New law gives foreign investors teeth in bite of China market", Retrieved from http://www.xinhuanet.com/english/2020-01/02/c_138674050.htm

Yadav, N., (2014), "The role of internet use on international trade: Evidence from Asian and Sub-Saharan African enterprises", Global Economy Journal, vol. 14, no. 2, pp. 198214.

Yongding, Y., (2018), "A trade war that is unwarranted", China \& World Economy, vol. 26, no. 5, pp. 38-61.

Zhou, Y., Wang, M., Hao, H., Johnson, L., \& Wang, H., (2015), "Plug-in electric vehicle market penetration and incentives: A global review", Mitigation and Adaptation Strategies for Global Change, vol. 20, pp. 777-795. 